\title{
Hubungan Stroke Iskemik dengan Gangguan Fungsi Kognitif di RS Universitas Sumatera Utara
}

\author{
Salsa Shafira Ramadhani ${ }^{1}$, Haflin Soraya Hutagalung ${ }^{1}$ \\ ${ }^{1}$ Departemen Neurologi, Fakultas Kedokteran, Universitas Sumatera Utara, Medan
}

\begin{abstract}
ABSTRAK
Latar Belakang: Stroke merupakan masalah kesehatan utama di dunia terutama di Benua Asia dengan penduduk lebih dari $60 \%$ populasi dunia. Selain menimbulkan masalah kesehatan stroke juga menjadi beban ekonomi dan sosial di negara yang berpendapatan rendah dan menengah. Stroke dapat menyebabkan gangguan fungsi kognitif sehingga pemeriksaan fungsi kognitif pada pasien stroke merupakan hal yang penting untuk dapat menentukan penanganan selanjutnya yang bertujuan memperbaiki fungsi kognitif. Tujuan: Penelitian ini bertujuan untuk menganalisis hubungan jenis kelamin, usia dan lama pendidikan dengan gangguan fungsi kognitif pada pasien pasca stroke iskemik di Rumah Sakit Universitas Sumatera Utara. Metode: Penelitian ini merupakan penelitian analitik menggunakan desain penelitian potong lintang dengan sampel penelitian pasien pasca stroke iskemik di poliklinik saraf di Rumah Sakit Universitas Sumatera Utara dipilih dengan metode consecutive sampling sebanyak 24 responden. Pengambilan data dilakukan dengan menggunakan rekam medik serta wawancara menggunakan kuisioner MoCA-Ina kepada responden. Hasil: Pada analisis uji chi square didapatkan jenis kelamin $(p=0,673)$ tidak berhubungan dengan gangguan fungsi kognitif pada pasien pasca stroke, sedangkan usia $(p=0,035)$ dan lama pendidikan $(p=0,013)$ menunjukkan hubungan dengan gangguan fungsi kognitif pada pasien pasca stroke iskemik. Kesimpulan: Terdapat hubungan antara usia dan lama pendidikan dengan gangguan fungsi kognitif, sedangkan jenis kelamin tidak menunjukkan adanya hubungan dengan gangguan fungsi kognitif pada pasien pasca stroke iskemik.
\end{abstract}

Kata kunci: fungsi kognitif, MoCA-Ina, pasca stroke iskemik, stroke iskemik

\begin{abstract}
Background: Stroke is a major health problem worldwide, especially in Asia, which has more than $60 \%$ of the world's population. Besides causing a health problem, stroke is also an economic and social burden in low and middle-income countries. Stroke may cause cognitive impairment, thus cognitive assessment in stroke survivors is important in addition to determine the treatment aimed at improving cognitive function following a stroke. Objectives: This study aims to determine the association between gender, age, and duration of education and cognitive impairment of post-stroke patients at Rumah Sakit Universitas Sumatera Utara. Methods: This study is an analytical research study using a cross-sectional design with a total of 24 respondents selected by consecutive sampling. Data collection was done by using medical records and interviewing the MoCA-Ina questionnaire to respondents. Results: On the analysis of chi-square obtained, gender value $p=0.673$ indicating there is no association between gender and cognitive impairment, age $(p=0.035)$ and duration of education ( $p=0.013)$ indicating there is an association between age as well as the duration of education and cognitive impairment of post-ischemic stroke patients. Conclusion: There is an association between age as well as the duration of education and cognitive impairment, whereas gender does not show association with cognitive impairment in post-ischemic stroke patients.
\end{abstract}

Keywords: cognitive function, ischemic stroke, MoCA-Ina, post ischemic stroke Received [31 Dec 2019] | Revised [18 Aug 2020] | Accepted [27 Aug 2020] 


\section{PENDAHULUAN}

Menurut World Health Organization (WHO), stroke adalah tanda-tanda klinis yang berkembang secara cepat akibat gangguan fungsi otak fokal atau global karena adanya sumbatan atau pecahnya pembuluh darah di otak dengan gejalagejala yang berlangsung selama 24 jam atau lebih tanpa penyebab lain selain gangguan vaskular. ${ }^{[1]}$ Manifestasi klinis atau gangguan saraf yang timbul akibat stroke tergantung dengan daerah otak yang pembuluh darahnya terkena. ${ }^{[2]}$ Stroke merupakan masalah utama kesehatan di Asia, dimana terdapat lebih dari $60 \%$ populasi manusia dunia dan kebanyakan negara di Asia merupakan negara berkembang. ${ }^{[3]}$

Selain menimbulkan masalah kesehatan, stroke juga menjadi beban ekonomi dan sosial di negara yang berpendapatan rendah dan menengah. ${ }^{[4]}$ Data Riset Kesehatan Dasar tahun 2018 menunjukkan peningkatan angka kejadian stroke di Indonesia yang terdiagnosis 7 dari 1.000 individu pada tahun 2013 menjadi 10,9 dari 1.000 individu pada tahun 2018. Prevalensi stroke tertinggi menurut umur adalah usia 75 tahun ke atas sebesar $50,2 \%$ dan terendah pada usia 15 24 tahun sebesar $0,6 \%$. ${ }^{[5]}$

Fungsi kognitif manusia merupakan kemampuan untuk mengintegrasikan masukan persepsi dengan cepat. ${ }^{[6]}$ Persepsi adalah interpretasi sadar seseorang terhadap dunia luar yang diciptakan oleh otak dari suatu pola impuls-impuls saraf yang diberikan kepadanya oleh reseptor (Gambar 1). Otak tersusun atas 100 miliar neuron yang membentuk anyaman kompleks yang memungkinkan untuk melakukan fungsi-fungsi kognitif luhur misalnya berpikir dan mengingat. Kognisi merujuk kepada tindakan atau proses "mengetahui", termasuk kesadaran dan penilaian. ${ }^{[7]}$ Gangguan fungsi kognitif merupakan kondisi kesulitan dalam mengingat, mempelajari hal-hal baru, membuat keputusan atau berkonsentrasi yang dialami seorang individu dan dapat menggangu kehidupan sehari-harinya. ${ }^{[8]}$

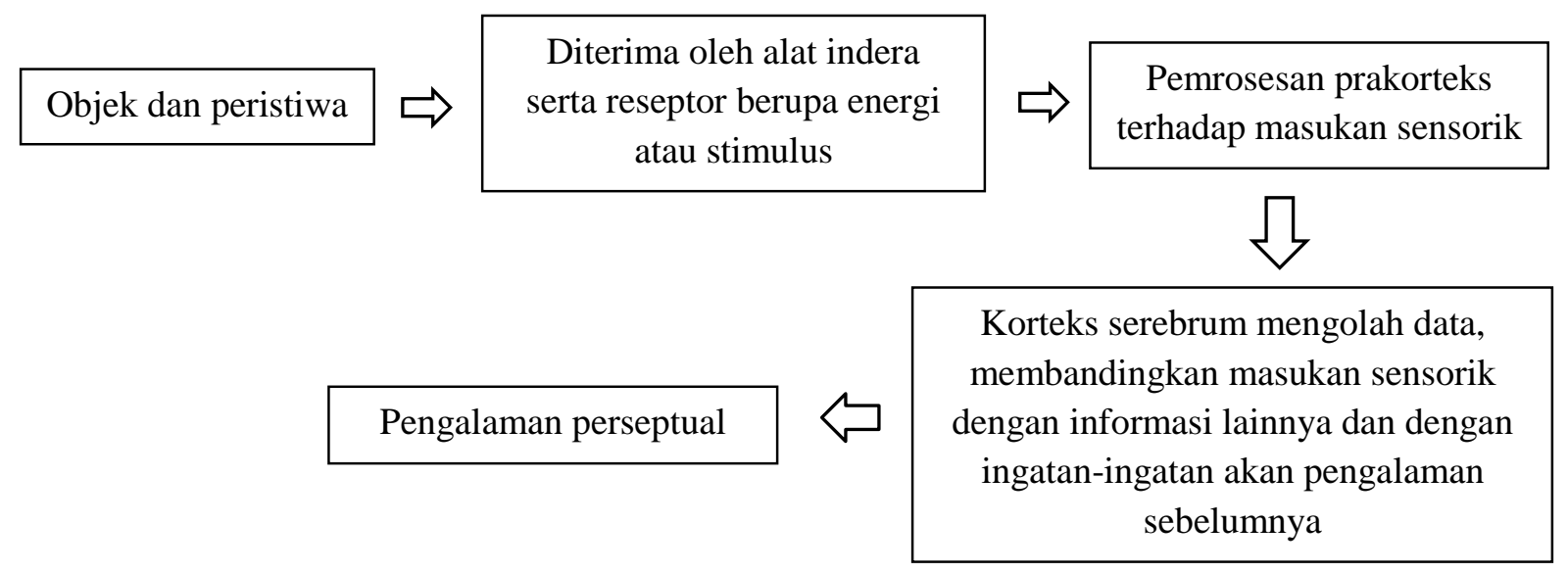

Gambar 1. Proses Terjadinya Persepsi ${ }^{[7]}$

Evaluasi fungsi kognitif pada penderita stroke merupakan hal yang penting karena dengan adanya gangguan pada satu atau beberapa domain fungsi kognitif yang dapat mempengaruhi proses penyembuhan dan rehabilitasi. Gangguan pada domain bahasa, kemampuan abstrak dan delayed recall berhubungan dengan lokasi stroke di hemisfer sebelah kiri. Sedangkan lesi di kedua hemisfer berhubungan dengan penurunan fungsi di beberapa domain yaitu visuospasial dan 
fungsi kognitif, penamaan, atensi dan orientasi. Salah satu tes yang dapat digunakan pada penderita stroke untuk mengukur fungsi kognitif adalah Montreal Cognitive Assesstment (MoCA). ${ }^{[9,10]}$ MoCA dapat dikerjakan dalam waktu 10 menit dengan total skor 30 poin dan mencakup delapan macam domain fungsi kognitif yaitu memori, fungsi eksekutif, visuospasial, bahasa, atensi, konsentrasi, orientasi, kemampuan abstrak dan penamaan. Total skor MoCA berjumlah kurang dari 26 dianggap terdapat gangguan kognitif. ${ }^{[11]}$ Pada $90 \%$ kasus stroke, MoCA dapat diselesaikan dalam kurun waktu kurang dari 10 menit. ${ }^{[12]}$

Penurunan fungsi kognitif meningkat pada pasien stroke dengan umur di atas 65 tahun. ${ }^{[13]}$ Sebanyak $47,3 \%$ penderita stroke mengalami gangguan kognitif setelah 3 bulan dari mulai terserang stroke pertamanya dan terdapat beberapa faktor risiko yang berhubungan dengan terjadinya gangguan kognitif tersebut antara lain usia tua, tingkat pendidikan yang rendah, riwayat diabetes mellitus dan silent infarcts. ${ }^{[14]}$

Gangguan kognitif berupa penurunan daya ingat atau disfungsi eksekutif dapat mengakibatkan seseorang kesulitan dalam melakukan aktivitas sehari-hari sehingga menurunkan kualitas hidup penderita. ${ }^{[15]}$ Penelitian ini dilakukan untuk menganalisis hubungan jenis kelamin, usia dan lama pendidikan pada pasien pasca stroke iskemik dengan gangguan fungsi kognitif.

\section{METODE}

Penelitian ini merupakan penelitian observasional analitik dengan desain cross-sectional yang dilakukan di Rumah Sakit Universitas Sumatera Utara dimulai antara bulan Juli 2019 sampai dengan bulan November 2019.

Populasi dalam penelitian ini adalah pasien pasca stroke iskemik yang didiagnosis melalui anamnesis, pemeriksaan fisik dan pemeriksaan CT scan yang berada di poli saraf Rumah Sakit Universitas Sumatera Utara. Sampel dalam penelitian ini diambil dengan metode consecutive sampling. Jumlah sampel berdasarkan rumus perhitungan perkiraan besar sampel didapati hasil sebanyak 24 responden. Kriteria inklusi pada penelitian ini adalah pasien pasca stroke iskemik poli saraf RS USU yang bersedia menjadi subjek penelitian, sedangkan kriteria ekslusi yaitu pasien dengan gangguan kesadaran, afasia, tuna aksara, demensia vaskular dan pasien dengan stroke batang otak.

Jenis data yang digunakan dalam penelitian adalah data primer, yaitu data yang diperoleh langsung dari subjek penelitian melalui wawancara menggunakan kuisioner MoCA-Ina dan data sekunder berupa data yang diperoleh secara tidak langsung yaitu jumlah pasien pasca stroke iskemik yang dirawat jalan di poli saraf Rumah Sakit Universitas Sumatera Utara. Sensitivitas MMSE (Mini Mental State Examination) dalam mendeteksi gangguan fungsi kognitif setelah terserang stroke berada di bawah kuesioner MoCA. ${ }^{[16]}$ Kuisioner MoCA-Ina adalah kuisioner MoCA dalam versi bahasa Indonesia yang sudah diuji validitas dan realibilitasnya di Indonesia. $^{[17]}$

Data yang terkumpul dianalisis dalam bentuk univariat untuk melihat distribusi frekuensi pasien pasca stroke iskemik berdasarkan jenis kelamin, usia dan lama pendidikan dan dianalisis dalam bentuk bivariat menggunakan uji chi square untuk melihat hubungan jenis kelamin, usia dan lama pendidikan dengan gangguan fungsi kognitif pada pasien pasca stroke iskemik di poli saraf Rumah Sakit Universitas Sumatera Utara.

\section{HASIL}

Penelitian dilakukan pada 24 orang pasien pasca stroke iskemik yang memenuhi kriteria penelitian. 
Tabel 1. Distribusi Frekuensi Pasien Pasca Stroke Iskemik berdasarkan Jenis Kelamin di Poli Saraf Rumah Sakit Universitas Sumatera Utara

\begin{tabular}{ccc}
\hline $\begin{array}{c}\text { Jenis } \\
\text { Kelamin }\end{array}$ & Frekuensi & $\begin{array}{c}\text { Persentase } \\
(\boldsymbol{\%})\end{array}$ \\
\hline Laki-laki & 15 & $62,5 \%$ \\
Perempuan & 9 & $37,5 \%$ \\
\hline Total & 24 & $100 \%$ \\
\hline
\end{tabular}

Berdasarkan Tabel 1, didapatkan bahwa dari 24 pasien pasca stroke iskemik di Poli Saraf Rumah Sakit Univeristas Sumatera Utara terdapat 15 orang berjenis kelamin laki-laki $(62,5 \%)$ serta 9 orang yang berjenis kelamin perempuan $(37,5 \%)$.

Tabel 2. Distribusi Frekuensi Pasien Pasca Stroke Iskemik berdasarkan Usia di Poli Saraf Rumah Sakit Universitas Sumatera Utara

\begin{tabular}{ccc}
\hline Usia & Frekuensi & $\begin{array}{c}\text { Persentase } \\
(\boldsymbol{\%})\end{array}$ \\
\hline$<60$ tahun & 15 & $62,5 \%$ \\
$\geq 60$ tahun & 9 & $37,5 \%$ \\
\hline Total & 24 & $100 \%$ \\
\hline
\end{tabular}

Tabel 2 menunjukkan bahwa dari 24 pasien pasca stroke iskemik di Poli Saraf Rumah Sakit Univeristas Sumatera Utara terdapat 15 orang yang berusia $<60$ tahun $(62,5 \%)$ serta 9 orang berusia $\geq 60$ tahun $(37,5 \%)$.

Tabel 3. Distribusi Frekuensi Pasien Pasca Stroke Iskemik berdasarkan Lama Pendidikan di Poli Saraf Rumah Sakit Universitas Sumatera Utara

\begin{tabular}{ccc}
\hline $\begin{array}{c}\text { Lama } \\
\text { Pendidikan }\end{array}$ & Frekuensi & $\begin{array}{c}\text { Persentase } \\
(\boldsymbol{\%})\end{array}$ \\
\hline$>12$ tahun & 10 & $41,7 \%$ \\
$\leq 12$ tahun & 14 & $58,3 \%$ \\
\hline Total & 24 & $100 \%$ \\
\hline
\end{tabular}

Tabel 3 menunjukkan bahwa dari 24 pasien pasca stroke iskemik di Poli Saraf Rumah Sakit Univeristas Sumatera Utara terdapat 10 orang yang berpendidikan $>12$ tahun $(41,7 \%)$ serta 10 orang yang berpendidikan $\leq 12$ tahun $(58,3 \%)$.

Tabel 4. Hubungan Jenis Kelamin dengan Gangguan Fungsi Kognitif pada Pasien Pasca Stroke Iskemik

\begin{tabular}{|c|c|c|c|c|c|c|c|c|}
\hline \multirow{3}{*}{$\begin{array}{c}\text { Jenis } \\
\text { Kelamin }\end{array}$} & \multicolumn{6}{|c|}{ Fungsi Kognitif } & \multirow{3}{*}{$p$} & \multirow{3}{*}{$\begin{array}{c}\text { PR } \\
(95 \% \mathrm{CI})\end{array}$} \\
\hline & \multicolumn{2}{|c|}{ Normal } & \multicolumn{2}{|c|}{ Gangguan } & \multicolumn{2}{|c|}{ Jumlah } & & \\
\hline & $\mathbf{N}$ & $\%$ & $\mathbf{N}$ & $\%$ & $\mathbf{N}$ & $\%$ & & \\
\hline Laki-laki & 8 & 66,7 & 7 & 58,3 & 15 & 62,5 & \multirow{3}{*}{0,673} & \multirow{3}{*}{$\begin{array}{c}1,429 \\
(0,271-7,518\end{array}$} \\
\hline Perempuan & 4 & 33,3 & 5 & 41,7 & 9 & 37,5 & & \\
\hline Jumlah & 12 & 100 & 12 & 100 & 24 & 100 & & \\
\hline
\end{tabular}

Berdasarkan Tabel 4, dapat dilihat bahwa responden yang berjenis kelamin laki-laki sebanyak 8 orang diantaranya $(66,7 \%)$ memiliki fungsi kognitif yang normal, sedangkan 7 orang $(58,3 \%)$ memiliki gangguan fungsi kognitif.
Responden yang berjenis kelamin perempuan sebanyak 4 orang $(33,3 \%)$ diantaranya memiliki fungsi kognitif normal, sementara 5 orang $(41,7 \%)$ memiliki gangguan fungsi kognitif.

Tabel 5. Hubungan Usia dengan Gangguan Fungsi Kognitif pada Pasien Pasca Stroke Iskemik

\begin{tabular}{|c|c|c|c|c|c|c|c|c|}
\hline \multirow{3}{*}{ Usia } & \multicolumn{6}{|c|}{ Fungsi Kognitif } & \multirow{3}{*}{$P$ Value } & \multirow{3}{*}{$\begin{array}{c}\text { PR } \\
(95 \% \mathrm{CI})\end{array}$} \\
\hline & \multicolumn{2}{|c|}{ Normal } & \multicolumn{2}{|c|}{ Gangguan } & \multicolumn{2}{|c|}{ Jumlah } & & \\
\hline & $\mathbf{N}$ & $\%$ & $\mathbf{N}$ & $\%$ & $\mathbf{N}$ & $\%$ & & \\
\hline$<60$ tahun & 10 & 83,3 & 5 & 41,7 & 15 & 62,5 & \multirow{3}{*}{$\mathbf{0 , 0 3 5}$} & \multirow{3}{*}{$\begin{array}{c}7,00 \\
(1,044- \\
46,949)\end{array}$} \\
\hline$\geq 60$ tahun & 2 & 16,7 & 7 & 58,3 & 9 & 37,5 & & \\
\hline Jumlah & 12 & 100 & 12 & 100 & 24 & 100 & & \\
\hline
\end{tabular}


Berdasarkan Tabel 5, dapat dilihat bahwa responden yang berusia $<60$ tahun sebanyak 10 orang diantaranya $(83,3 \%)$ memiliki fungsi kognitif yang normal, sedangkan 5 orang $(41,7 \%)$ memiliki gangguan fungsi kognitif. Responden yang berusia $\geq 60$ tahun sebanyak 2 orang $(16,7 \%)$ diantaranya memiliki fungsi kognitif normal, sementara 7 orang $(58,3 \%)$ memiliki gangguan fungsi kognitif.

Tabel 6. Hubungan Lama Pendidikan dengan Gangguan Fungsi Kognitif pada Pasien Pasca Stroke Iskemik

\begin{tabular}{|c|c|c|c|c|c|c|c|c|}
\hline \multirow{3}{*}{$\begin{array}{c}\text { Lama } \\
\text { Pendidikan }\end{array}$} & \multicolumn{6}{|c|}{ Fungsi Kognitif } & \multirow{3}{*}{$P$ Value } & \multirow{3}{*}{$\begin{array}{c}\text { PR } \\
(95 \% \mathrm{CI})\end{array}$} \\
\hline & \multicolumn{2}{|c|}{ Normal } & \multicolumn{2}{|c|}{ Gangguan } & \multicolumn{2}{|c|}{ Jumlah } & & \\
\hline & $\mathbf{N}$ & $\%$ & $\mathbf{N}$ & $\%$ & $\mathbf{N}$ & $\%$ & & \\
\hline$\leq 12$ tahun & 4 & 33,3 & 10 & 83,3 & 14 & 58,3 & \multirow{3}{*}{0,013} & \multirow{3}{*}{$\begin{array}{c}0,1 \\
(0,014-0,693)\end{array}$} \\
\hline$>12$ tahun & 8 & 66,7 & 2 & 16,7 & 10 & 41,7 & & \\
\hline Jumlah & 12 & 100 & 12 & 100 & 24 & 100 & & \\
\hline
\end{tabular}

Berdasarkan Tabel 6, dapat dilihat bahwa responden dengan lama pendidikan $\leq 12$ tahun sebanyak 4 orang diantaranya $(33,3 \%)$ memiliki fungsi kognitif yang normal, sedangkan 10 orang $(83,3 \%)$ memiliki gangguan fungsi kognitif. Responden dengan lama pendidikan $>12$ tahun sebanyak 8 orang $(66,7 \%)$ diantaranya memiliki fungsi kognitif normal, sementara 2 orang $(16,7 \%)$ memiliki gangguan fungsi kognitif.

\section{PEMBAHASAN}

Dari hasil penelitian, didapatkan bahwa 7 orang $(58,3 \%)$ pasien pasca stroke iskemik berjenis kelamin laki-laki dan 5 orang $(41,7 \%)$ berjenis kelamin perempuan mengalami gangguan fungsi kognitif. Uji chi square dilakukan untuk menganalisis ada tidaknya hubungan jenis kelamin pada pasien pasca stroke iskemik di Poli Saraf Rumah Sakit Universitas Sumatera Utara dengan gangguan fungsi kognitif. Hasil nilai uji chi square menunjukkan nilai $p=0,673(p>0,05)$ maka $\mathrm{H}_{0}$ gagal ditolak yang menunjukkan tidak ada hubungan yang signifikan antara jenis kelamin dengan gangguan fungsi kognitif pada pasien pasca stroke iskemik.

Hasil yang didapatkan sejalan dengan penelitian yang dilakukan oleh Tumiwa et al. di Rumah Sakit Bethesda Yogyakarta, dimana pada penelitiannya terhadap 110 responden, 51 orang $(70,8 \%)$ yang berjenis kelamin laki-laki dan 24 orang $(63,2 \%)$ berjenis kelamin perempuan mengalami gangguan fungsi kognitif. Hasil uji chi square pada penelitiannya diperoleh hasil nilai $p=0,411(p>0,05)$ yang menandakan bahwa tidak ada hubungan jenis kelamin dengan gangguan fungsi kognitif pada pasien pasca stroke iskemik. ${ }^{[18]}$

Demensia vaskular lebih sering terjadi pada laki-laki daripada perempuan, tetapi banyak penelitian yang menemukan bahwa tidak ada perbedaan yang signifikan antara jenis kelamin dengan risiko demensia pasca stroke. Hal ini berkaitan dengan peran adiponektin sebagai neuroprotektif. Penurunan kadar serum adiponektin yang berhubungan dengan proses penuaan ditemukan lebih banyak pada perempuan daripada pria. ${ }^{[19]}$

Uji chi square juga dilakukan untuk menganalisis ada tidaknya hubungan usia pasien pasca stroke iskemik di Poli Saraf Rumah Sakit Universitas Sumatera Utara dengan gangguan fungsi kognitif. Hasil nilai uji chi square menunjukkan nilai $p=$ $0,035(p<0,05)$ maka $\mathrm{H}_{0}$ ditolak dan $\mathrm{H}_{\mathrm{a}}$ diterima yang menunjukkan ada hubungan yang signifikan antara usia dengan gangguan fungsi kognitif pada pasien pasca stroke iskemik. 
Hasil penelitian ini sesuai dengan penelitian yang dilakukan oleh Tumiwa et al. di Rumah Sakit Bethesda Yogyakarta diperoleh hasil nilai $p=0,007(p<0,05)$ yang menandakan bahwa terdapat hubungan usia dengan gangguan fungsi kognitif pada pasien pasca stroke iskemik. ${ }^{[18]}$

Vascular cognitive impairment (VCI) merupakan terminologi yang mencakup defisit kognitif yang luas mulai dari gangguan kognitif ringan sampai demensia yang dihubungkan dengan faktor risiko vaskular. ${ }^{[20]}$ VCI cenderung lebih umum terjadi seiring bertambahnya usia. Semakin bertambahnya usia akan diiringi dengan perubahan yang terjadi pada pembuluh darah, salah satunya peningkatan kolagen dan penurunan elastin yang terjadi di antara usia $20-90$ tahun akan menyebabkan meningkatnya penebalan tunika intima-media sebanyak 3 kali lipat. Penebalan pembuluh darah arteri akan menyebabkan penurunan fungsi kognitif. Hampir semua penyakit pembuluh darah yang dapat menyebabkan meningkatnya penebalan pembuluh darah akan memengaruhi fungsi kognitif seseorang. ${ }^{[21]}$ Penelitian yang dilakukan oleh Dong et al. untuk mendeteksi VCI pasca stroke akut pada 100 penderita stroke menunjukkan bahwa 18 dari 57 penderita stroke dengan skor MMSE dalam rentang normal mengalami gangguan kognitif yang diukur dengan MoCA, sedangkan hanya 2 dari 41 penderita stroke dengan skor MoCA dalam rentang normal yang memiliki skor rendah pada pemeriksaan MMSE. ${ }^{[16]}$

Hasil uji chi square antara lama pendidikan dengan gangguan fungsi kognitif pada pasien pasca stroke iskemik didapatkan nilai $p=0,013(p<0,05)$ maka $\mathrm{H}_{0}$ ditolak dan $\mathrm{H}_{\mathrm{a}}$ diterima yang menunjukkan ada hubungan yang signifikan antara lama pendidikan dengan gangguan fungsi kognitif pada pasien pasca stroke iskemik. Hasil penelitian ini sesuai dengan penelitian yang dilakukan di RSUDZA Banda Aceh diperoleh hasil nilai $p=0,000(p<0,05)$ menunjukkan bahwa terdapat hubungan antara lama pendidikan dengan gangguan fungsi kognitif pada pasien pasca stroke iskemik. $^{[22]}$

Penelitian yang dilakukan oleh Saeed et al. didapatkan hasil bahwa semakin tingginya tingkat pendidikan seseorang maka semakin menurunnya risiko untuk terjadinya penurunan fungsi kognitif setelah stroke atau TIA yang didukung oleh adanya peranan cognitive reserve atau cadangan kognitif yang merupakan kemampuan seseorang dalam mentoleransi perubahan patologi di otak terkait usia. Subjek dengan tingkat pendidikan yang lebih tinggi menunjukkan bahwa pengaruh stroke atau TIA menunujukkan hanya sedikit perubahan terhadap fungsi eksekutif dan daya ingat dan dapat beradaptasi lebih baik terhadap kerusakan serebrovaskular yang mengindikasikan adanya peranan cadangan kognitif. Cadangan kognitif ini dapat dikembangkan dengan aktivitas yang menstimulasi secara kognitif seperti menjalani pendidikan dan pekerjaan. Cadangan kognitif yang tinggi tersebut memungkinkan seorang individu untuk dapat meminimalkan dampak kerusakan yang disebabkan oleh stroke atau TIA karena adanya efisiensi yang lebih baik atau kapasitas neuron yang lebih besar sebelum terjadinya kerusakan atau kompensasi yang lebih baik setelah terjadinya kerusakan. Selain itu, aktivitas yang menstimulasi secara kognitif seperti mengikuti pendidikan tidak hanya dapat menyebabkan neurogenesis tetapi juga bisa menstimulasi brain-derived neurotrophic factor (BDNF) yang berhubungan dengan peningkatan plastisitas otak. ${ }^{[23]}$

Individu dengan lama pendidikan atau tingkat pendidikan yang tinggi biasanya memiliki lingkungan atau perilaku yang lebih baik seperti gaya hidup yang lebih sehat, akses yang lebih baik ke pelayanan kesehatan dan kepatuhan terhadap pengobatan yang lebih baik juga. Perilaku tersebut bisa menyebabkan tingkat keparahan stroke yang tidak terlalu buruk, 
pergi ke pelayanan kesehatan saat mulai timbul gejala stroke sehingga komplikasi stroke yang dapat terjadi lebih sedikit. ${ }^{[22]}$

\section{KESIMPULAN}

Berdasarkan hasil penelitian yang dilakukan pada 24 orang pasien pasca stroke iskemik di poli saraf Rumah Sakit Universitas Sumatera Utara, dapat ditarik kesimpulan bahwa jenis kelamin responden terbanyak adalah laki-laki sebanyak 15 orang $(62,5 \%)$, mayoritas usia responden di bawah 60 tahun sebanyak 15 orang $(62,5 \%)$ dan lama pendidikan responden terbanyak adalah $\leq 12$ tahun sebanyak 14 orang $(58,3 \%)$.

Hasil analisis uji chi square didapatkan jenis kelamin $(p=0,673)$ tidak berhubungan dengan gangguan fungsi kognitif pada pasien pasca stroke iskemik, sedangkan usia $(p=0,035)$ dan lama pendidikan $(p=0,013)$ menunjukkan hubungan dengan gangguan fungsi kognitif pada pasien pasca stroke iskemik.

\section{SARAN}

Penelitian ini dapat dilakukan lebih lanjut kelak pada pasien pasca stroke iskemik yang didiagnosis dengan diffusion-weighted MRI, lalu mencantumkan distribusi pasien pasca stroke iskemik berdasarkan lokasi infark dan lebih menspesifikkan lokasi lesi stroke di regio otak tertentu agar dapat dianalisis hubungannya dengan gangguan fungsi kognitif.

\section{DAFTAR PUSTAKA}

[1] Coupland AP, Thapar A, Qureshi MI, Jenkins H, Davies AH. The definition of stroke. J R Soc Med. 2017;110(1):9-12. doi: 10.1177/0141076816680121

[2] Hammer GD, McPhee SJ. Pathophysiology of disease: an introduction to clinical medicine. $8^{\text {th }}$ ed. New York: McGraw-Hill; 2018.

[3] Feigin VL, Krishnamurthi RV,
Parmar P, Norrving B, Mensah GA, Bennett DA, et al. Update on the global burden of ischemic and hemorrhagic stroke in 1990-2013: The GBD 2013 study. Neuroepidemiology. 2015;45(3):161-76. doi: $\underline{10.1159 / 000441085}$

[4] Yan LL, Li C, Chen J, Miranda JJ, Luo R, Bettger J, et al. Prevention, management, and rehabilitation of stroke in low- and middle-income countries. eNeurologicalSci. 2016;2(8):21-30. doi: 10.1016/j.ensci.2016.02.011

[5] Badan Penelitian dan Pengembangan Kesehatan Kementerian Kesehatan RI. Riset Kesehatan Dasar 2018 [Internet]. Jakarta: Kementerian Kesehatan RI; 2018. Available from: http://www.kesmas.kemkes.go.id/ass ets/upload/dir_519d41d8cd98f00/file s/Hasil-riskesdas-2018 1274.pdf

[6] Huettig F, Mishra RK, Olivers CN. Mechanisms and representations of language-mediated visual attention. Front Psychol; 2012;2(January):111. doi: $10.3389 /$ fpsyg.2011.00394

[7] Sherwood L. Fisiologi manusia dari sel ke sistem. $8^{\text {th }}$ ed. Ong HO, Mahode AA, Ramadhani D, editors. Jakarta: EGC; 2014.

[8] Centers for Disease Control and Prevention. Cognitive impairment: a call for action now! [Internet]. Atlanta (GA): Centers for Disease Control and Prevention; 2011. Available from: https://www.cdc.gov/aging/pdf/cogn itive_impairment/cogimp_poilicy_fi nal.pdf

[9] Pasi M, Salvadori E, Poggesi A, Inzitari D, Pantoni L. Factors predicting the Montreal cognitive assessment ( MoCA ) applicability and performances in a stroke unit. $\mathbf{J}$ Neurol. 2013;260(6):1518-26. doi: 10.1007/s00415-012-6819-5

[10] Sagnier S, Munsch F, Bigourdan A, et al. The infuence of stroke location 
on cognitive and mood impairment. A voxel-based lesion-symptom mapping study. J Stroke Cerebrovasc Dis. 2019;28(5):1236-42. doi: 10.1016/j.jstrokecerebrovasdis.2019. $\underline{01.010}$

[11] Cumming TB, Churilov L, Linden T, Bernhardt J. Montreal Cognitive Assessment and Mini-Mental State Examination are both valid cognitive tools in stroke. Acta Neurol Scand. 2013;128(2):122-9. doi: 10.1111/ane.12084

[12] Blackburn DJ, Bafadhel L, Randall M, Harkness KA. Cognitive screening in the acute stroke setting. Age Ageing. 2013;42(1):113-6. doi: 10.1093/ageing/afs116

[13] Sun J-H, Tan L, Yu J-T. Post-stroke cognitive impairment: epidemiology, mechanisms and management. Ann Transl Med. 2014;2(8):80. doi: 10.3978/j.issn.2305-5839.2014.08.05

[14] Jacquin A, Binquet C, Rouaud O, Graule-Petot A, Daubail B, Osseby $\mathrm{GV}$, et al. Post-stroke cognitive impairment: High prevalence and determining factors in a cohort of mild stroke. J Alzheimer's Dis. 2014;40(4):1029-38.

[15] Kapoor A, Lanctot KL, Bayley M, Herrmann N, Murray BJ, Swartz RH. Screening for post-stroke depression and cognitive impairment at baseline predicts long-term patient-centered outcomes after stroke. J Geriatr Psychiatry Neurol. 2019;32(1):40-8. doi: $\underline{10.1177 / 0891988718819859}$

[16] Dong Y, Kumar VK, Chan BP, Venketasubramanian N, Teoh HL, Seet RC, et al. The Montreal Cognitive Assessment (MoCA) is superior to the Mini-Mental State Examination (MMSE) for the detection of vascular cognitive impairment after acute stroke. J Neurol Sci. 2010;299(1-2):15-8. doi: $10.1016 / j . j n s .2010 .08 .051$

[17] Rambe AS, Fitri FI. Correlation between the Montreal Cognitive Assessment-Indonesian Version (Moca-INA) and the Mini-Mental State Examination (MMSE) in Elderly. Open Access Maced J Med Sci. 2017;5(7):915-9. doi: 10.3889/oamjms.2017.202

[18] Tumiwa F, Pinzon RT, Kunci K. Hubungan hipertensi dengan gangguan fungsi kognitif pada pasien post-stroke iskemik di RS Bethesda. Jurnal Kedokteran YARSI. 2017;25(3):135-44. doi: 10.33476/jky.v25i3.368

[19] Kalaria RN, Akinyemi R, Ihara M. Stroke injury, cognitive impairment and vascular dementia. Biochim Biophys Acta. 2016;1862(5):915-25. doi: 10.1016/j.bbadis.2016.01.015

[20] Direktorat Jenderal Pelayanan Kesehatan Kementerian Kesehatan RI. Demensia pada Stroke [Internet]. Jakarta: Kementerian Kesehatan RI; 2018. Available from: http://yankes.kemkes.go.id/readdemensia-pada-stroke-3628.html

[21] Gorelick PB, Scuteri A, Black SE, DeCarli C, Greenberg SM, Iadecola $\mathrm{C}$, et al. Vascular contributions to cognitive impairment and dementia: a statement for healthcare professionals from the American Heart Association/American Stroke Association. Stroke. 2011;42(9):2672-713. doi: 10.1161/STR.0b013e3182299496

[22] Amalia TQ. Faktor-faktor yang berhubungan dengan gangguan fungsi kognitif pada pasien pasca stroke iskemik di RSUDZA Banda Aceh [Skripsi]. Banda Aceh: Universitas Syiah Kuala; 2013.

[23] Saeed S, Portegies ML, Wolters FJ, Hofman A, Koudstaal PJ, Tiemeier $\mathrm{H}$, et al. Higher education is associated with a lower risk of dementia after a stroke or TIA. The Rotterdam Study. Neuroepidemiology. 2016;46(2):120 -7. doi: $10.1159 / 000443649$ 